\title{
Description of Hymenolepis microstoma (Nottingham strain): a classical tapeworm model for research in the genomic era
}

\author{
Lucas J Cunningham, Peter D Olson
}

\begin{abstract}
Background: Hymenolepis microstoma (Dujardin, 1845) Blanchard, 1891, the mouse bile duct tapeworm, is a rodent/beetle-hosted laboratory model that has been used in research and teaching since its domestication in the 1950s. Recent characterization of its genome has prompted us to describe the specific strain that underpins these data, anchoring its identity and bringing the 150+ year-old original description up-to-date.

Results: Morphometric and ultrastructural analyses were carried out on laboratory-reared specimens of the 'Nottingham' strain of Hymenolepis microstoma used for genome characterization. A contemporary description of the species is provided including detailed illustration of adult anatomy and elucidation of its taxonomy and the history of the specific laboratory isolate.

Conclusions: Our work acts to anchor the specific strain from which the H. microstoma genome has been characterized and provides an anatomical reference for researchers needing to employ a model tapeworm system that enables easy access to all stages of the life cycle. We review its classification, life history and development, and briefly discuss the genome and other model systems being employed at the beginning of a genomic era in cestodology.
\end{abstract}

\section{Background}

Species of Hymenolepis Weinland, 1858 (Platyhelminthes: Cestoda: Cyclophyllidea) have been used as tapeworm models in research and teaching since the 1950s when they were first domesticated in the laboratory of Clark P. Read [1]. Adult parasites of rodents with beetle intermediate hosts, they benefit from easy culture in vivo using natural hosts that are themselves model organisms (e.g. Mus musculus L., Tribolium confusum Jacquelin du Val). Research on Hymenolepis, and especially $H$. diminuta (Rudolphi, 1819), H. nana (von Siebold, 1852) and H. microstoma, is underpinned by an extensive literature that includes much of our classical knowledge of tapeworm biology [e.g. [2]]. A recently initiated effort sponsored by The Wellcome Trust Sanger Institute to characterize the genome and adult and larval transcriptomes of $H$. microstoma http://www. sanger.ac.uk/sequencing/Hymenolepis/microstoma/ has

\footnotetext{
* Correspondence: P.Olson@nhm.ac.uk

* Correspondence: P.Olson@nhm.ac.uk London, SW7 5BD, UK
}

(0) 2010 Cunningham and Olson; licensee BioMed Central Ltd. This is an Open Access article distributed under the terms of the Creative Commons Attribution License (http://creativecommons.org/licenses/by/2.0), which permits unrestricted use, distribution, and reproduction in any medium, provided the original work is properly cited. greatly advancing its utility for researchers interested in employing a practical tapeworm system that allows access to all life cycle stages. In light of this development, and the fact that laboratory isolates can vary in features of their biology [3], it is desirable to have a description of the exact strain on which the genome is based, and to thus anchor the data to a well-defined entity.

Hymenolepis microstoma was first described from the bile ducts of mice in 1845 by Dujardin [4] who placed it in the genus Taenia L., 1758, which housed all tapeworms known at that time. In 1891, Blanchard [5] transferred the species to the genus Hymenolepis and provided an expanded description of the species. Although Bear and Tenora [6] suggested synonymy between $H$. microstoma and $H$. straminea (Goeze, 1782), species status of $H$. microstoma historically has been widely accepted, and molecular data have shown both species to represent independent, albeit closely related, lineages $[7,8]$. In contrast, the genus Hymenolepis has 
itself been overhauled on several occasions and its membership and internal structure remain controversial. For example, whereas Hughes $[9,10]$ accepted the generic assignment $H$. microstoma by Blanchard, Spasskii [11] subdivided the genus and transferred $H$. microstoma to the genus Rodentolepis Spasskii, 1954, which he erected to house the rodent-hosted species of Hymenolepis with armed rostella. At the same time Spasskii erected the genus Vampirolepis Spasskii, 1954, which Schmidt subsequently considered a senior synonym of Rodentolepis, thus resulting in the new combination Vampirolepis microstoma (Dujardin, 1854) Schmidt, 1986 [12]. The genus Rodentolepis was retained by Czaplinski and Vaucher [13] in the most recent synoptic treatment of tapeworms [14], but this work did not consider species level taxa and therefore did not arbitrate on the generic assignment of $H$. microstoma. Thus although Vampirolepis microstoma [12] represents the most recent formal taxonomic assignment of the species, few investigators have adopted this name, and most reports refer to it as either a member of the genus Hymenolepis, or with less frequency, Rodentolepis. In our view, a natural circumscription of hymenolepid species will not be attained without the application of molecular data [15].

To this end, Haukisalmi et al. [8] recently used $28 \mathrm{~S}$ rDNA to analyze phylogenetic relationships among 32 hymenolepidid species from rodents, shrews and bats, showing that both Hymenolepis and Rodentolepis represented paraphyletic assemblages. Although their work assigned $H$. microstoma to a 'Rodentolepis' clade, the lack of resolution and widespread paraphyly of the taxa in their analyses indicate that greater taxonomic representation and more robust data are needed before such nomenclatural circumscriptions can be made reliably. We therefore follow Blanchard [5] in recognizing the mouse bile duct tapeworm as a member of the genus Hymenolepis, employing the most common name in usage, whilst appreciating that a more comprehensive understanding of hymenlepidid interrelationships is likely to warrant generic reassignment.

Here we provide a description of a 'Nottingham' strain of $H$. microstoma based on light and scanning electron microscopy of laboratory-reared specimens from the same culture used to characterize the genome. History of the isolate, dating back to the laboratory of C. P. Read [1], suggests that it represents a model that has been widely employed and disseminated within the parasitological community for over 50 years, making the genome data directly relevant to a significant pre-existing literature on its biology.

\section{Results}

Description of Hymenolepis microstoma (Nottingham strain) Hymenolepis microstoma (Dujardin, 1845) Blanchard, 1891

\section{Recorded synonyms}

Taenia microstoma Dujardin, 1845; Cercocystis tenebrionis Villot, 1882; Cysticercus tenebrionis (Villot, 1882) Leuckart, 1886; Cysticercus taenia-microstomae Dolly, 1894; Cysticercoides tenebrionis (Villot, 1882) Braun, 1898; Scolex (= Onchoscolex) decipiens (Diesing, 1853) Joyeux and Kobozieff, 1928; Rodentolepis microstoma (Dujardin, 1845) Spasskii, 1954; Vampirolepis microstoma (Dujardin, 1845) Schmidt, 1986.

\section{Common name}

mouse bile duct tapeworm

Laboratory strain designation

'Nottingham'

\section{Laboratory strain history}

2005-present, The Natural History Museum, London (PDO); 1977-2005, University of Nottingham, UK (Prof. Jerzy Behnke); 1964-1977, University of Glasgow, UK (Prof. Adrian Hopkins); before 1964, Texas Rice University, USA (Prof. Clark P. Read).

\section{Laboratory hosts}

flour beetles (Tribolium confusum) and BKW outbred conventional mice (Mus musculus).

\section{Voucher specimens}

20 whole-mounted specimens (BMNH 2010.12.8.1-20), 22 slides of histological sections of adult worms (scolex and neck: BMNH 2010.12.8.21-30; immature strobila: BMNH 2010.12.8.31-36; mature strobila: BMNH 2010.12.8.37-42), and 12 whole and partial specimens prepared for SEM, retained by the corresponding author.

\section{No. chromosomes}

12 diploid, all acrocentric [16,17]

Genome size

$\sim 140 \mathrm{Mb}$ (haploid)

\section{Genome data}

http://www.sanger.ac.uk/resources/downloads/helminths/hymenolepis-microstoma.html

\section{Description}

(based on 14-16 day old in vivo laboratory-reared specimens: 20 whole-mounted, 2 sectioned, and 12 specimens prepared for SEM; Figures. 1-2; all measurements are given as length $\times$ width in $\mu \mathrm{m}$ except where noted): worms anapolytic, weakly craspedote, $4.7(2.5-8.1) \mathrm{cm}$ long, with 659 (291-1,087) total segments (Figure 1A); scolex $138(116-157) \times 232(204-284)$ with four muscular suckers $102(79-129) \times 96$ (76-113) (Figure 1B). Rostellum $38(26-52) \times 71(51-75)$ with an irregular surface lacking microtriches (Figures. 2A, B), armed with 25 (22-26) hooks, retractable into contractile rostellar pouch $104(83-139) \times 101(79-140)$ (Figure 1B). Hooks cricetoid; $\alpha=13.9, \beta=12.3, \gamma=6, \gamma^{\prime}=4.4$ (Figure $1 C$ ). Width at level of neck 175 (94-225). Immature segments $62(38-83) \times 404(437-463)$, mature segments 117 (70$167) \times 729(360-887)$, gravid terminal segments 164 

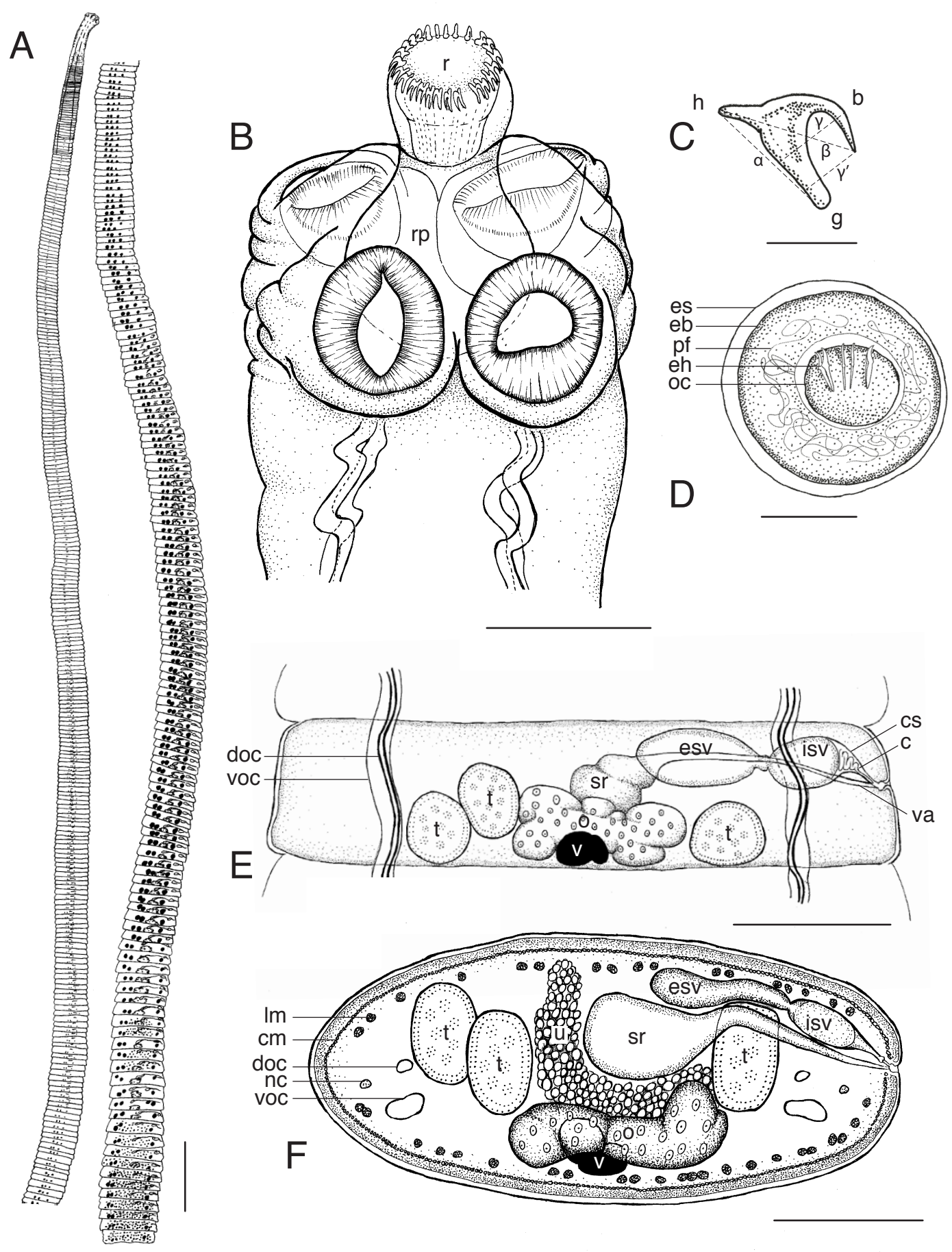

Figure 1 Illustrations of adult Hymenolepis microstoma (Nottingham strain). A. Whole worm. B. Hook showing measurement vectors. C. Egg. D. Scolex. E. Mature proglottide. F. Cross section of mature proglottide. Abbreviations: b, blade; c, cirrus; cs, cirrus sac; doc, dorsal osmoregulatory canal; eb, embryophore; eh, embryonic hooks; es, eggshell; esv, external seminal vesicle; g, guard; h, handle; isv, internal seminal vesicle; nc, nerve cord; o, ovary; oc, oncosphere; pf; polar filaments; r, rostellum; rp, rostellar bulb; s, shell; sr, seminal receptacle; t, testis; $u$, uterus; va, vagina; voc, ventral osmoregulatory canal. Scale bars: $A=1 \mathrm{~mm} ; \mathrm{B}=10 \mu \mathrm{m} ; \mathrm{C}=50 \mu \mathrm{m} ; \mathrm{D}-\mathrm{F}=100 \mu \mathrm{m}$. 

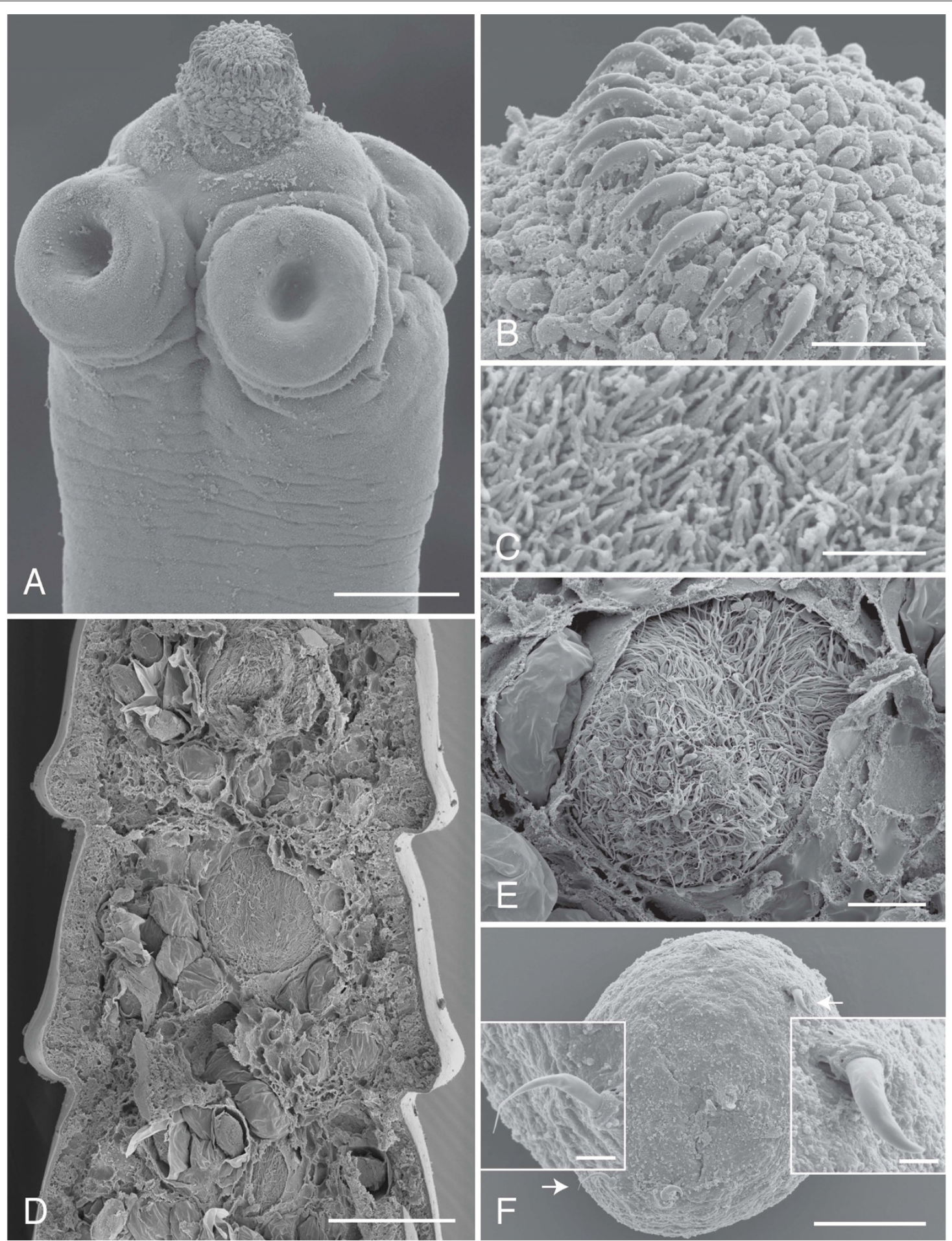

Figure 2 Scanning electron micrographs of adult Hymenolepis microstoma (Nottingham strain). A. Scolex and rostellum. B. Rostellar hooks. C. Microtriches on the scolex. D. Internal view of gravid strobila. E. Seminal receptacle with spermatozoa surrounded by eggs. F. Three-day old transforming oncosphere showing larval hooks (arrows and insets). Scale bars: $A=50 \mu \mathrm{m} ; B=5 \mu \mathrm{m} ; C=2 \mu \mathrm{m} ; \mathrm{D}=100 \mu \mathrm{m} ; \mathrm{E}-\mathrm{F}=20 \mu \mathrm{m}$ (insets $=2 \mu \mathrm{m}$ ). 
$(131-262) \times 1,160(454-1,426)$. Paired osmoregulatory vessels and longitudinal nerve cords lateral (Figure 1E, F). Entire worm covered by short ( 2 um), uniform and densely packed filiform microtriches [18] (Figure 2C).

Male system consisting of three spherical to oval testes $72(51-114) \times 78(61-115)$, arranged one poral and two aporal (occasionally reversed in individual proglottides). Vas deferens expands to form an external seminal vesicle $105(73-195) \times 56(38-93)$ (Figure 1E) . Cirrus pouch ovoid 58 (45-99) $\times 153$ (97-302), enclosing coiled cirrus and internal seminal vesicle, 52 (38$93) \times 94(72-195)$. Female system consisting of a central lobed ovary $63(34-103) \times 234$ (130-360) partially overlapping a compact vitellarium 38 (41-94) $\times 56$ (32-68). Seminal receptacle median. Vagina $299(197-431) \times 13$ (9-18) situated ventral to male system (Figure 1F). Common genital pore dextral, unilateral, near mid-point of margin. Eggs thin-shelled (Figure 2E), enclosing embryophore with 3 polar filaments and oncosphere with embryonic hooks arranged in parallel (Figure 1D).

\section{Remarks}

Hymenolepis species exhibit the well-documented 'crowding effect' in which overall size and egg production are inversely related to the intensity of infection [19]. Consequently, size is dependent not only on the age of the worms, but on the number of worms present in the host, and cannot be used diagnostically [20]. Crowding in H. microstoma has been shown to decrease linear growth, egg production and the rate of proglottide formation [21]. Moreover, we chose to document gravid adult specimens at an age and size most useful for laboratory manipulations in which larger worms pose unnecessary practical problems (e.g. assays involving whole mount in situ hybridization or in vitro culture). de Rycke [22] showed that H. microstoma is in rapid state of growth starting around 12-14 days post-infection in Mus musculus, and whereas our length measurements correspond to those reported by de Rycke for the relevant age class (see Table 1), they are obviously less comparable to reports based on older specimens, such as those stemming from natural infections.

\section{Discussion}

Life history

Hymenolepis microstoma is most probably cosmopolitan in distribution [20] and is not known from human infections outside of a single report in which mixed infections of $H$. nana and $H$. microstoma were identified in four individuals from a remote region of Western Australia [23]. Reported natural definitive hosts include a large range of rodent genera that include mice (e.g. Apodemus Kaup, Dendromus Smith, Leggada Gray, Mastomys Thomas, Mus L.), gerbils (Meriones Illiger) and voles (Microtus Schrank) $[9,12,24]$. Infections in rats is controversial: whereas Joyeux and Kobozieff [25] reported successful infection of laboratory rats, Dvorak et al. [20] found rats to be refractory to H. microstoma, and Litchford [24] showed that rats became refractory with age. Similarly, although infections can be established in golden hamsters (Mesocricetus Nehring), they result in underdeveloped worms and cause severe pathology to the host [20,24]. Dvorak et al. [20] demonstrated that mice could not be infected via eggs, as is the case with $H$. nana (ie. auto-infection) [26]. However, in congenitally athymic mice, Andreassen et al. [27] found that autoinfection was possible, showing that oncospheres penetrated the intestinal tissues and developed into cysticeroids that subsequently excysted and developed normally in the bile duct and duodenum, in a manner similar to the direct cycle of $H$. nana. Autoinfection of BALB/c mice was also implied by the detection of stage-specific antigens [28].

The life history of $H$. microstoma (Figure 3 ) has been described in detail previously $[20,25,29]$ and is typical of other hymenolepid species, save its unusual location in the bile duct of the mammalian host. In brief, eggs containing patent oncospheres are expelled with faeces into the environment and may be ingested by either the adult or larval stage of an appropriate beetle host (e.g. Tribolium confusum, T. castaneum, Tenebrio molitor, and Oryzaephilus surinamensis). Oncospheral larvae $(\sim 20 \mu \mathrm{m}$; Figure 1D; Figure 2F) are released from their thin shells (Figure 2E; n.b. appearing as a 'hymen' via light microscopy and the eponym of the genus) through the action of the host mouthparts, and after ingestion use their three pairs of hooks and proteolytic secretions [30] to enter the haemocoel. There they undergo a complete metamorphosis, reconstituting their bodies into cycsticeroid larvae [31] in approximately seven days, the phases of which have been documented by both Voge [32] and Goodchild and Stullken [33]. Upon infection of the definitive host, the combination of pepsin and $\mathrm{HCl}$ in the stomach act to dissolve the larval membranes, and juvenile worms are then activated in the duodenum in response to trypsin and bile salts. de Rycke [22] described adult growth and organogenesis in Mus musculus (summarized in Table 1): in the first three days the juveniles move anteriorly in the upper $20 \%$ of the small intestine and duodenum before establishing permanently in the bile duct, where they commence strobilation. Within approximately 14 days terminal segments are gravid and most of their strobila extends outside of the bile duct and into the duodenum. Thus the entire life cycle, from egg to gravid adult, can be completed in the laboratory in only three weeks. Although the germinative ('neck') region of tapeworms has the potential for 'immortality' as demonstrated in $H$. diminuta by 
Table 1 Growth of Hymenolepis microstoma in Mus musculus (summarized from de Rycke [22])

\begin{tabular}{lcl}
\hline Days p.i. & Avg. length $(\mathbf{m m})$ & Development and position in gut \\
\hline $\mathbf{1 - 2}$ & $0.25-0.50$ & no external segmentation or genital anlagen; worms localized in the first $10-20 \mathrm{~cm}$ of the intestine \\
$\mathbf{3}$ & 1.58 & some internal segmentation; appearance of genital anlagen; worms localized in the first $10 \mathrm{~cm}$ of the intestine \\
$\mathbf{4 - 5}$ & $3.40-3.85$ & external segmentation and male \& female genital anlagen discernable; worms localized in the bile duct \\
$\mathbf{6}$ & 5.85 & testes in few segments \\
$\mathbf{7}$ & 9.15 & testes mature \\
$\mathbf{8}$ & 13.50 & early-mature to mature proglottides \\
$\mathbf{9 - 1 0}$ & $17-20.50$ & all proglottides mature \\
$\mathbf{1 1}$ & 27 & disappearance of female glands; few pre-oncospheres \\
$\mathbf{1 2}$ & 36 & pre-oncospheres, no hooks \\
$\mathbf{1 3}$ & $\mathbf{4 6 . 5}$ & semi-gravid proglottides \\
$\mathbf{1 4}$ & 62.5 & near gravid proglottides \\
$\mathbf{1 5 - 1 6}$ & $94-129$ & gravid proglottides \\
\hline
\end{tabular}

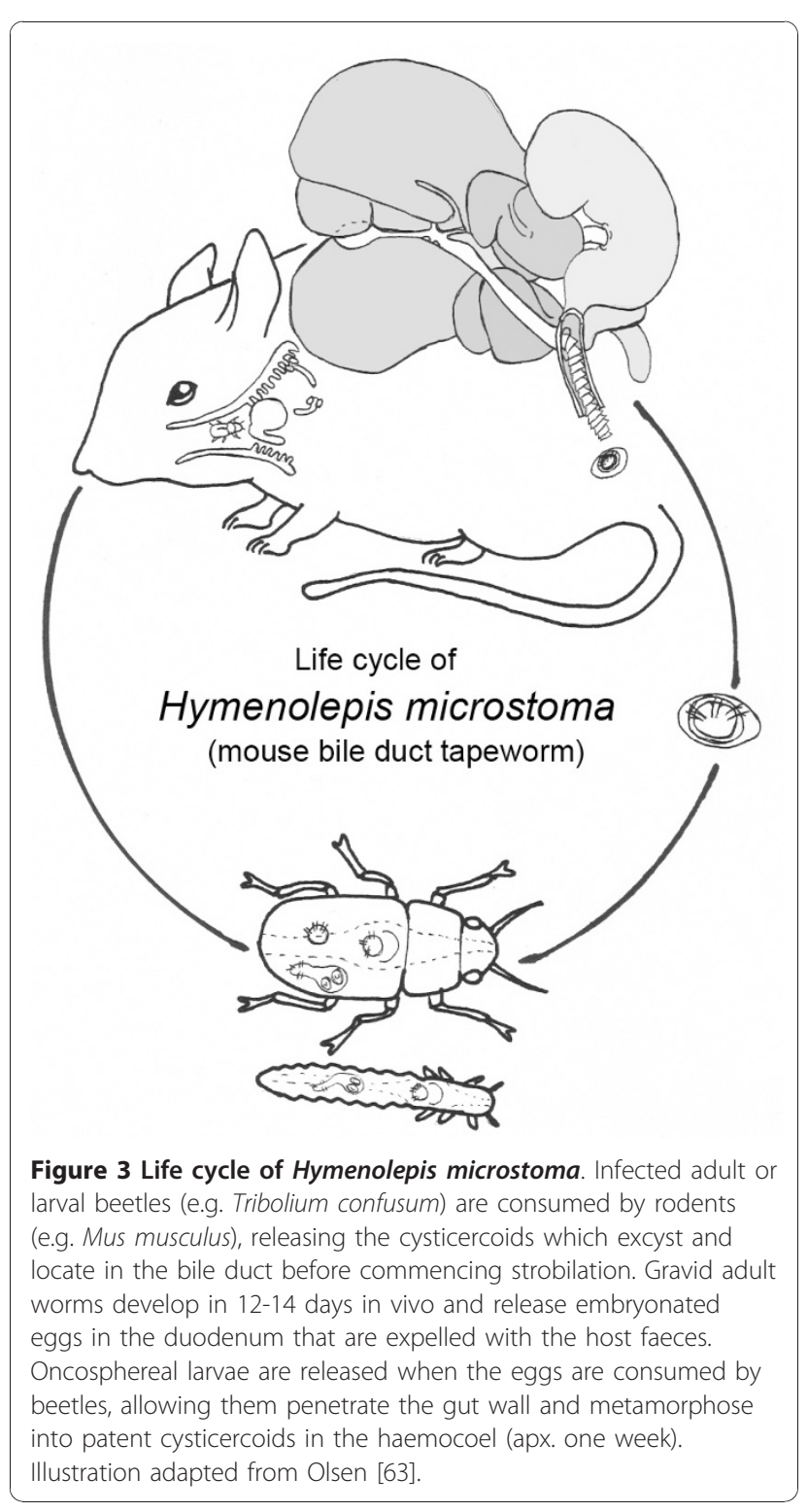

Read [34], infections of $H$. microstoma in mice persist for an average of six months, whereas those in the intermediate host can remain infective for the life of the beetle (> one year).

\section{The Hymenolepis genome}

Through collaboration with The Wellcome Trust Sanger Institute, a draft genome of $H$. microstoma derived from the cultures described herein is now publically available: http://www.sanger.ac.uk/resources/downloads/helminths /hymenolepis-microstoma.html. The latest assembly (October 2010) includes more than $40 \times$ coverage of the estimated $140 \mathrm{Mb}$ haploid genome and is based on data produced by a combination of Roche 454 and Illumina Solexa next-generation sequencing technologies. Gene annotation is presently being conducted using a combination of RNA-Seq [35] and automated gene prediction tools, revealing intron-exon structures and other aspects of their genomic organization, and additional tools are being used to characterize non-coding regions (M. Zarowiecki and M. Berriman, pers. comm.).

Hymenolepis microstoma is one of four tapeworm species to have complete genomes characterized: a reference genome of Echinococcus multilocularis Leukart, 1863 and draft genome of E. granulosus (Batsch, 1786) have been produced by the Sanger Institute (available from http:// www.sanger.ac.uk/resources/downloads/helminths/) in collaboration with Profs. Klaus Brehm and Cecelia Fernandez, respectively, and a consortium in Mexico are currently working to characterize the genome of Taenia solium L., 1758 [36]. These data herald the beginning of the genomic era in cestodology and are already accelerating advances in our understanding of tapeworm biology and infection. At present the only published platyhelminth genome is that of the human blood fluke, Schistosoma mansoni Sambon, 1907 [37]. However, genome data for Schistosoma Weinland, 1858 and Echinococcus Rudolphi, 1801, as well as the free-living flatworm 
models Schmidtea mediterranea Benazzi, Baguna, Ballester, Puccinelli and Del Papa, 1975 [38] and Macrostomum lignano Ladurner, Scharer, Salvenmoser and Rieger, 2005 (http://www.macgenome.org/), have been available for some time and full reports on the characteristics of all of these genomes, including that of $H$. microstoma, are expected soon.

\section{Model systems in the genomic era of cestodology}

Of the three Hymenolepis species that have been employed in laboratory research, most literature concerns the rat tapeworm $H$. diminuta, followed by the medically important dwarf tapeworm, $H$. nana, and finally by the mouse bile duct tapeworm, $H$. microstoma. As a model for research in the genomic age, however, H. microstoma has advantages over both of these alternative systems. For example, compared to $H$. diminuta, it is both smaller and mouse-hosted, enabling smaller, and thus less expensive, assay sizes (e.g. for RNAi), as well as less expensive animal costs, whereas the mousehosted H. nana is both a human pathogen (albeit controversy persists regarding the conspecficity of human and mouse strains) and capable of infecting other laboratory animals through faecal contamination via its direct life cycle [26]. Moreover, whereas $H$. nana survives only weeks in the mouse host [39], H. microstoma persist for $\sim 6$ months and thus require less frequent passage. Although the smaller size of $H$. nana would be preferable for assays, on balance $H$. microstoma provides the best practical solution for contemporary research programmes that wish to employ a tapeworm model providing easy access to all stages of their life cycle at minimal expense and risk to human and animal health.

Completion of the H. microstoma life cycle in vitro from egg to gravid adult was demonstrated in the 1960s and 70s by De Rycke and Berntzen [40], Evans [41,42] and Seidel $[43,44]$, but to our knowledge no report of research employing these techniques has been published subsequently. Our initial attempts to follow these protocols for the cultivation of adult worms resulted in only limited growth ( $3 \times$ increase in length) without the onset segmentation (unpub. data). However, as many of the reported media used by previous authors are no longer commercially available, more work is needed to develop contemporary protocols for in vitro culture. Among the most advanced in vitro systems available for tapeworm research today has been developed by Brehm and colleagues for Echinococcus [45-48], the genus on which most of our understanding of tapeworm molecular biology is based [49]. Development of an axenic culture system of the hydatid stage of $E$. multilocularis has allowed them to introduce transgenic and functional genomic techniques (e.g. RNAi) to cestodology, and their system is currently being used to pioneer research on stem-cells and developmental biology in parasitic flatworms $[45,50]$. Although not yet supported by genome characterization, another currently employed in vitro system is that of Mesocestoides Vaillant, 1863 [e.g. [51]] which are readily maintained in the larval tetrathyridial stage [31] and can increase their numbers in culture via asexual fission [52]. Adult worms have also been grown in vitro and induced to strobilate through the addition of bile salts [53]. However, as with species of Echinoccocus and Taenia, in vivo development of strobilar stages of Mesocestoides is prohibited by the legalities and expense of maintaining large vertebrate hosts in the laboratory. Rodent hosted Hymenolepis species therefore remain the most convenient systems for research on the biology of adult tapeworms, and for this reason we have been developing $H$. microstoma as a model to study the development and evolution of tapeworm segmentation [54].

Although the basic framework of cestode evolution has been revealed by previous molecular studies [55-58] and the interrelationships of select groups are now well resolved [59-61], there has yet to be a comprehensive molecular phylogenetic study of the largest and most important group of tapeworms with regard to human and animal health, the Cyclophyllidea. All of the tapeworm species for which genomes have been characterized thus far belong to this order and thus it is especially important that we elucidate the relative phylogenetic positions of the $350+$ described genera [14] Such knowledge will provide an evolutionary underpinning for comparative genomic studies within the group and allow us to identify the sister lineages whose genomes share the closest evolutionary histories to the species for which full genome data are now available.

\section{Methods}

A seed culture of Hymenolepis microstoma infected beetles was obtained from Nottingham University in 2005 courtesy of Prof. Jerzy Behnke and subsequently maintained in vivo at the Natural History Museum (London) using flour beetles (Tribolium confusum) and BKW outbred conventional mice (full protocols can found at http://www.olsonlab.com; please contact the corresponding author to enquire about seed cultures). Gravid, 14-16 day old specimens were removed from the bile ducts and duodenum of mice and quickly swirled in near-boiling $0.85 \%$ saline for $\sim 4$ secs to fully extend the worms prior to fixation in cold $4 \%$ paraformaldehyde overnight at $-4 \mathrm{C}$. Whole-mounted specimens were dehydrated in a graded ethanol series, stained using Gill's haematoxylon or left unstained, cleared in beachwood creosote and mounted in Canada balsam. Sections were prepared by paraffin embedding using standard histological techniques and stained with Mayer's Haemalum [62]. Measurements and illustrations were made 
under differential interference contrast on a Leica DM5000B compound microscope equipped with a camera lucida and digital documentation system. Specimens used for SEM were dehydrated as above, critically-point dried, sputter-coated with gold/palladium and viewed on a JEOL XL30 scanning electron microscope. Internal structures were imaged by SEM by cutting worms crudely using a razor blade.

\section{Acknowledgements}

We thank especially Jerzy Behnke for providing a seed culture of $H$. microstoma and for assistance in tracking the history of the laboratory isolate. Special thanks also to Matt Berriman, Magdalena Zarowiecki and Alejandro Sanchez-Flores for leading the genome initiative at the Wellcome Trust Sanger Institute. Thanks to Jayne King and Natasha PouchkinaStantcheva for assistance with maintenance of the model, to Dave Cooper for histological sectioning, and to Lauren Howard and Alex Ball for assistance with SEM. Thanks also to Rod Bray for commenting on an earlier draft of the manuscript. This work was supported in part by a BBSRC grant to PDO (BBG0038151).

This work is dedicated to the memory of Clark P. Read: father of the Hymenolepis model and a scientist who was in his time "Parasitology's ambassador to the fields of physiology, biochemistry and molecular biology" [1].

\section{Authors' contributions}

PDO designed the study and drafted the manuscript. LC carried out research. Both authors read and approved the final manuscript.

\section{Competing interests}

The authors declare that they have no competing interests.

Received: 10 November 2010 Accepted: 31 December 2010 Published: 31 December 2010

\section{References}

1. Stewart GL, Lumsden RD, Fisher FM: The contributions of Clark P. Read on ecology of the vertebrate gut and its parasites. Bios 1975, 46:3-21.

2. Arai HP: Biology of the tapeworm Hymenolepis diminuta. New York: Academic Press; 1980.

3. Pappas PW, Leiby DA: Variation in the sizes of eggs and oncospheres and the numbers and distributions of testes in the tapeworm, Hymenolepis diminuta. J Parasitol 1986, 72:383-391.

4. Dujardin MF: Histoire Naturelle des Helminthes ou vers intestinaux. 1845, 1-680.

5. Blanchard R: Histoire Zoologique et Médicale des Téniadés du genre Hymenolepis Weinland. Paris; 1891.

6. Bear JG, Tenora F: Some species of Hymenolepis (Cestoidea) from rodents and from primates. Acta Scientarium Naturalium Academiae Scientarium Bohemoslovacae-Brno 1970, 4:1-32.

7. Casanova JC, Santalla F, Durand P, Vaucher C, Feliu C, Renaud F: Morphological and genetic differentiation of Rodentolepis straminea (Goeze, 1752) and Rodentolepis microstoma (Dujardin, 1845) (Hymenolepididae). Parasitol Res 2001, 87:439-444.

8. Haukisalmi V, Hardman LM, Foronda P, Feliu C, Laakkonen J, Niemimaa J, Lehtonen JT, Henttonen $\mathrm{H}$ : Systematic relationships of hymenolepidid cestodes of rodents and shrews inferred from squences of 285 ribosomal RNA. Zool Scr 2010, 39:631-641.

9. Hughes RC: The genus Hymenolepis Weinland 1858. Oklahoma Agricultural and Mechanical College Agricultural Experiment Station 1940, 8:1-42.

10. Hughes RC: A key to the species of tapeworms in Hymenolepis. Trans Am Microsc Soc 1941, 60:378-414.

11. Spasskii AA: Classification of Hymenolepididae from mammals. $\mathrm{Tr}$ Gel'mintol Lab 1954, 7:120-167.

12. Schmidt GD: Handbook of Tapeworm Identification. Boca Raton, Florida: CRC Press; 1986
13. Czaplinski B, Vaucher C: Family Hymenolepididae Ariola, 1899. In Keys to the Cestode Parasites of Vertebrates. Edited by: Khalil LF, Jones A, Bray RA. Wallingford, U.K.: CAB International; 1994:595-663.

14. Khalil LF, Jones A, Bray RA, eds: Keys to the Cestode Parasites of Vertebrates. Wallingford: CAB International; 1994.

15. Olson PD, Tkach W: Advances and trends in the molecular systematics of the parasitic Platyhelminthes. Adv Parasitol 2005, 60:165-243.

16. Hossain MM, Jones AW: The chromosomes of Hymenolepis microstoma (Dujardin 1845). J Parasitol 1963, 49:305-307.

17. Proffitt MR, Jones AW: Chromosome analysis of Hymenolepis microstoma. Exp Parasitol 1969, 25:72-84

18. Chervy L: Unified terminology for cestode microtriches: a proposal from the International Workshops on Cestode Systematics in 2002-2008. Folia Parasitol 2009, 56:199-230.

19. Read CP: The "Crowding Effect" in tapeworm infections. J Parasitol 1951, 37:174-178.

20. Dvorak JA, Jones AW, Kuhlman HH: Studies on the biology of Hymenolepis microstoma (Dujardin, 1845). J Parasitol 1961, 47:833-838.

21. Jones AW, Tan BD: Effect of crowding upon the growth and fecundity in the mouse bile duct tapeworm, Hymenolepis microstoma. J Parasitol 1971, 57:88-93.

22. de Rycke PH: Development of the cestode Hymenolepis microstoma in Mus musculus. Zeitschrift fur Parasitenkunde 1966, 27:350-354.

23. Macnish MG, Ryan UM, Behnke JM, Thompson RCA: Detection of the rodent tapeworm Hymenolepis (= Rodentolepis) microstoma in humans: a new zoonosis? Int J Parasitol 2003, 33:1079-1085.

24. Litchford RG: Observations on Hymenolepis microstoma in three laboratory hosts: Mesocricetus auratus, Mus musculus, and Rattus novegicus. J Parasitol 1963, 49:403-410.

25. Joyeux C, Kobozieff NI: Recherches sur I'Hymenolepis microstoma (Dujardin, 1845). Annales de Parasitologie 1928, 6:59-79.

26. Heyneman D: Auto-reinfection in white mice resulting from infection by Hymenolepis nana. J Parasitol 1953, 39:28.

27. Andreassen J, Ito A, Ito M, Nakao M, Nakaya K: Hymenolepis microstoma: direct life cycle in immunodeficient mice. J Helminthol 2004, 78:1-5.

28. Ito A, Itoh M, Andreassen J, Onitake K: Stage-specific antigens of Hymenolepis microstoma recognized in BALB/C mice. Parasite Immunol 1989, 11:453-462.

29. Hickman JL: The biology of Hymenolepis microstoma (Dujardin). Pap Proc R Soc Tasman 1964, 98:73-77.

30. Fairweather I, Threadgold LT: Hymenolepis nana: the fine structure of the 'penetration gland' and nerve cells within the oncosphere. Parasitology 1981, 82:445-458.

31. Chervy L: The terminology of larval cestodes or metacestodes. Syst Parasitol 2002, 52:1-33.

32. Voge M: Development of Hymenolepis microstoma (Cestoda: (yclophyllidea) in the intermediate host Tribolium confusum. J Parasitol 1964, 50:77-80.

33. Goodchild CG, Stullken RE: Hymenolepis microstoma: cysticercoid morphologenesis. Trans Am Microsc Soc 1970, 89:224-229.

34. Read CP: Longevity of the tapeworm, Hymenolepis diminuta. J Parasitol 1967, 53:1055

35. Wang Z, Gerstein M, Snyder M: RNA-Seq: a revolutionary tool for transcriptomics. Nat Rev Genet 2009, 10:57-63.

36. Santamaría Rl, Soberón X, de la Torre P, Valdés V, Yánez J: The Taenia solium genome. Parasitol Int 2005, 55:S127-S130.

37. Berriman M, Haas BJ, Loverde PT, Wilson RA, Dillon GP, Cerqueira GC, Mashiyama ST, Al-Lazikani B, Andrade LF, Ashton PD, et al: The genome of the blood fluke Schistosoma mansoni. Nature 2009, 460:352-358.

38. Sánchez Alvarado A, Newmark PA, Robb SMC, Juste R: The Schmidtea mediterranea database as a molecular resource for studying platyhelminthes, stem cells and regeneration. Development 2002, 129:5659-5665.

39. Ito A, Smyth JD: Adult cestodes. In Immune responses in parasitic infections: immunology, immunopathology, and immunoprophilaxis. Volume 2. Edited by: Soulsby EJL. Boca Raton: CRC Press; 1987:115-163.

40. de Rycke PH, Berntzen AK: Maintenance and growth of Hymenolepis microstoma (Cestoda: Cyclophyllidea) in vitro. J Parasitol 1967, 53:352-354.

41. Evans WS: The in vitro cultivation of Hymenolepis microstoma from cysticercoid to egg-producing adult. Can J Zool 1970, 48:1135-1137. 
42. Evans WS: The cultivation of Hymenolepis in vitro. In Biology of the tapeworm Hymenolepis diminuta. Edited by: Arai HP. New York: Academic Press; 1980:425-448.

43. Seidel JS: Hemin as a requirement in the development in vitro of Hymenolepis microstoma (Cestoda: Cyclophyllidea). J Parasitol 1971, 57:566-570.

44. Seidel JS: The life cycle in vitro of Hymenolepis microstoma (Cestoda). J Parasitol 1975, 61:677-681.

45. Brehm K: Echinococcus multilocularis as a model in stem cell research and molecular host-parasite interaction. Parasitology 2010, 137:537-555.

46. Brehm K, Spiliotis M: Recent advances in the in vitro cultivation and genetic manipulation of Echinococcus multilocularis metacestodes and germinal cells. Exp Parasitol 2008, 119:506-515.

47. Spiliotis M, Lechner S, Tappe D, Scheller C, Krohne G, Brehm K: Transient transfection of Echinococcus multilocularis primary cells and complete in vitro regeneration of metacestode vesicles. Int I Parasitol 2008, 38:1025-1039.

48. Spiliotis M, Mizukami C, Oku Y, Kiss F, Brehm K, Gottstein B: Echinococcus multilocularis primary cells: Improved isolation, small-scale cultivation and RNA interference. Mol Biochem Parasitol 2010, 174:83-87.

49. Hemphill A, Kern P: Special issue: Experimental studies in Echinococcus. Exp Parasitol 2008, 119:437-438.

50. Brehm K: The role of evolutionary conserved signalling systems in Echinococcus multilocularis development and host-parasite interaction. Med Microbiol Immunol 2010, 199:247-259.

51. Koziol U, Dominguez MF, Marin M, Kun A, Castillo E: Stem cell proliferation during in vitro development of the model cestode Mesocestoides corti from larva to adult worm. Front Zool 2010, 7:1-12.

52. Sprecht D, Voge M: Asexual multiplication of Mesocestoides tetrathyrdidia in laboratory animals. J Parasitol 1965, 51:268-272.

53. Markoski MM, Bizarro CV, Farias S, Espinoza I, Galanti N, Zaha A, Ferreira HB: In vitro segmentation induction of Mesocestoides corti (Cestoda) tetrathyridia. J Parasitol 2003, 89:27-34.

54. Olson PD: Hox genes and the parasitic flatworms: New opportunities, challenges and lessons from the free-living. Parasitol Int 2008, 57:8-17.

55. Olson PD, Caira JN: Evolution of the major lineages of tapeworms (Platyhelminthes: Cestoidea) inferred from 18S ribosomal DNA and elongation factor-1a. J Parasitol 1999, 85:1134-1159.

56. Olson PD, Littlewood DTJ, Bray RA, Mariaux J: Interrelationships and evolution of the tapeworms (Platyhelminthes: Cestoda). Mol Phylogenet Evol 2001, 19:443-467.

57. Olson PD, Poddubnaya LG, Littlewood DTJ, Scholz T: On the position of Archigetes and its bearing on the early evolution of the tapeworms. J Parasitol 2008, 94:898-904.

58. Waeschenbach A, Webster BL, Bray RA, Littlewood DTJ: Added resolution among ordinal level relationships of tapeworms (Platyhelminthes: Cestoda) with complete small and large subunit nuclear ribosomal RNA genes. Mol Phylogenet Evol 2007, 45:311-325.

59. Healy CJ, Caira JN, Jensen K, Webster B, Littlewood DTJ: Proposal for a new tapeworm order, Rhinebothriidea. Int J Parasitol 2009, 39:497-511.

60. Kuchta R, Scholz T, Brabec J, Bray RA: Suppression of the tapeworm order Pseudophyllidea (Platyhelminthes: Eucestoda) and the proposal of two new orders, Bothriocephalidea and Diphyllobothriidea. Int I Parasitol 2008, 38:49-55.

61. Olson PD, Caira JN, Jensen K, Overstreet RM, Palm HW, Beveridge I: Evolution of the trypanorhynch tapeworms: parasite phylogeny supports independent lineages of sharks and rays. Int J Parasitol 2010, 40:223-242.

62. Cooper D: The preparation of serial sections of platyhelminth parasites, with details of the materials and facilities required. Syst Parasitol 1988, 12:211-229.

63. Olsen OW: Animal parasites: their biology and life cycles. Minneapolis: Burgess Publishing Co; 1962.

doi:10.1186/1756-3305-3-123

Cite this article as: Cunningham and Olson: Description of Hymenolepis microstoma (Nottingham strain): a classical tapeworm model for research in the genomic era. Parasites \& Vectors 2010 3:123.

\section{Submit your next manuscript to BioMed Central and take full advantage of:}

- Convenient online submission

- Thorough peer review

- No space constraints or color figure charges

- Immediate publication on acceptance

- Inclusion in PubMed, CAS, Scopus and Google Scholar

- Research which is freely available for redistribution 